\title{
Tongue Rolling and Tongue Folding Traits in an African Population
}

\author{
Rasgos de Lengua Enrollada y Lengua Doblada en una Población Africana \\ "Emmanuel Igho Odokuma; ** Ovocity Eghworo; *Godwin Avwioro \& "Ufuoma Agbedia
}

ODOKUMA, E. I.; EGHWORO, O.; AVWIORO, G. \& AGBEDIA, U. Tongue rolling and tongue folding traits in an African population. Int. J. Morphol., 26(3):533-535, 2008.

SUMMARY: Genetic variations that occur in humans are usually as a result of a plethora of factors which are of enormous value from physical anthropological window especially in studying population variation and human diversity. This study was conducted amongst unrelated volunteer students of Delta State University, Nigeria who were all of Urhobo tribe (71 males) and (72) females aged between 18 years and over to determine their ability to roll or fold the tongues. The frequency of folders (120) and rollers (87) were more common than non-folders (23) and non-rollers (56). The incidence of tongue rolling was higher in females than in their male counterparts. These differences did not however show any statistical significance, $\mathrm{p}>0.01$. The frequency of R-F was observed to be highest in both males and females (38 and 43) respectively. 22 males and 17 females were observed to be capable of fold but unable to roll their tongue. None rollers and none folders were 9 males and 7 females respectively while rollers and none-folders were the least with frequencies of 2 males and 3 females respectively.

KEY WORDS: Traits; Nigerian; Tongue roller; Tongue folder; Gender.

\section{INTRODUCTION}

The tongue is a highly muscular organ of deglutition, taste and speech. The motor innervation to the tongue is via the hypoglossal nerve. The exception is the palatoglossus which receives its innervation from the pharyngeal plexus. Although, relatively little is known about the motor neurons innervating the intrinsic muscles of the tongue, a recent tract tracing study in Cynomolgus monkey has revealed that motor neurons of the medial divisions of the hypoglossal nucleus innervate tongue muscles that are oriented in planes transverse to the long axis of the tongue, whereas motor neurons of the lateral divisions innervate tongue muscles that are oriented parallel to this axis (Sokoloff \& Deacon, 1992).

Genetic variations that occur in humans are usually a result of a plethora of factors which may include selection, migration, gene - flow and genetic drift (Bhasin et al., 1992). Research on tongue movement has been previously conducted (Sturtevant, 1940). The dominant gene is responsible for folding and rolling of the tongue lateral edges of the tongue while the inability to roll and fold the tongue is associated with the recessive gene (Hsu, 1948). Later Liu \& Hsu (1949) expressed the inverse. Some other researchers have opined that these traits are not genetically controlled but learned (Whittinghill, 1970). Though the genetic mechanism of control is still been argued, these traits are of enormous value from physical anthropological window especially in studying population variation and human diversity (Ghandhi, 1976). Although several European and Asian populations have been investigated (Whittinghill; Bulliyya, 2003), very little data exist amongst Africans. This is perhaps the first amongst the Urhobo tribe in Nigeria, Africa.

\section{MATERIAL AND METHOD}

This study was conducted amongst unrelated volunteer students of Delta Stale University, Nigeria who were all of Urhobo tribe (71 males) and (72 females) aged between 18 years and over. (Figs. 1 and 2). Standard methods

\footnotetext{
* Department of Anatomy, Delta State University, Abraka Nigeria.

** Department of Physiology, Delta State University Abraka, Nigeria.
} 
were applied in recording the ability for tongue folding (Liu \& Hsu) and tongue rolling (Sturtevant). Each of the subjects was asked to roll the two lateral edges of the tongue without the aid of the teeth. Those who could roll the tongue were designated as rollers and those who could fold their tongues were designated folders. For the study of combination of tongue movements, four types were recorded namely, ability to roll and fold the tongue (R-F), ability to roll but inability to fold the tongue (R-N), ability to fold but inability to roll the tongue (N-F) and inability to fold or roll the tongue (N$\mathrm{N})$. Results were arranged according to gender to ascertain the occurrence of sexual dimorphism. Chi-square tests $x^{2}$ were used in the analyses of the data obtained since the data was nominal from a simple randomized design (Andy, 1992).

\section{RESULTS}

Tables I and II, show the frequency distribution of tongue rollers and tongue folders amongst Urhobo people of Nigeria. The frequency of folders, Fig. 1 (120) and rollers, Fig. 2 (87) were more common than non-folders (23) and non-rollers (56). The incidence of tongue rolling was higher in females than in their male counterparts. These differences did not however show any statistical significance, $\mathrm{p}>$ 0.01. The combination of tongue movements was shown in Table III. The frequency of R-F was observed to be highest in both males and females (38 and 43) respectively. 22 males and 17 females were able to fold their tongues but were unable to roll their tongues. None rollers and none folders were 9 males and 7 females respectively while rollers and none-folders were the least with frequencies of 2 males and 3 females, respectively. $\mathrm{X}^{2}$ values for combination traits were found to show no significant deference in gender in all the combination groups' $\mathrm{p}>0.01$.

Table I. Distribution of tongue rolling and tongue folding in the studied population tongue rolling.

\begin{tabular}{lccc}
\hline Character & Male & Female & Total \\
Rollers & 39 & 48 & 87 \\
Non rollers & 31 & 25 & 56 \\
& 70 & 73 & 143 \\
\hline
\end{tabular}

Table II. Tongue folding.

\begin{tabular}{lccc}
\hline Character & Male & Female & Total \\
Folders & 59 & 61 & 120 \\
Non folders & 11 & 12 & 23 \\
& 70 & 73 & 143 \\
\hline
\end{tabular}

Table III. Frequency distribution of combination of tongue movements in the studied population.

\begin{tabular}{lccc}
\hline Character combination & Males & Females & Total \\
R-F & 38 & 43 & 81 \\
R-NF & 2 & 5 & 7 \\
F-NR & 22 & 17 & 39 \\
NR-NF & 9 & 7 & 16 \\
Total & 71 & 72 & 143 \\
\hline
\end{tabular}

R-F: Ability to roll and fold the tongue, R-N: Ability to roll but inability to fold the tongue, N-F: Ability to fold but inability to roll the tongue, NR-NF: Inability to fold or roll the tongue.

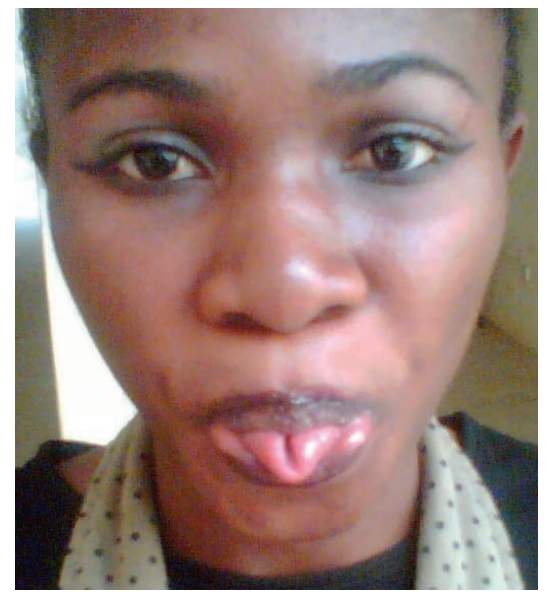

Fig. 1. Tongue rolling.

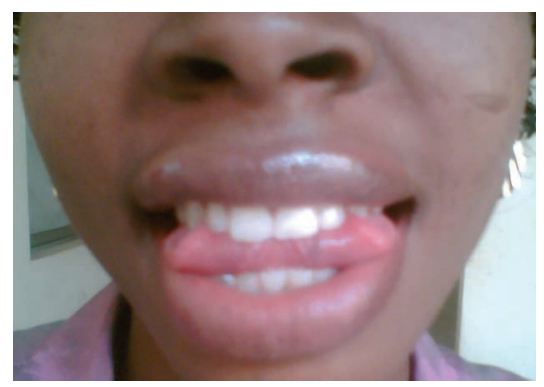

Fig. 2. Tongue folding.

\section{DISCUSSION}

It was observed that the incidence of tongue rollers and tongue folders was higher in females when compared with their male counterparts in the studied population. Females also predominated in the rolling and folding traits and also the rolling and non folding combination traits. A higher percentage of males were observed to exhibit folding and non rolling pattern and the non-folding and non-rolling patterns, respectively. These findings were not different from previous studies as reported by Hernandez. (1980) that showed that ability to roll the tongue in males was $63.1 \%$, 
while their female counterparts accounted for $66.84 \%$ in the population studied. A similar study amongst Indians showed no significant difference between male and female samples but a lower incidence of tongue rollers and folders (Bulliyya).

These findings suggest that tongue folding and rolling traits are possibly products of autosomal genes. It is likely that observed variations in distributions of these traits may be as a result of selective expression arising from natural selection. It is also possible that the overlap of motor neuron pools innervating similarly oriented extrinsic and intrinsic muscles may facilitate the simultaneous recruitment of these muscles although this has not been studied. No significant difference in gender distribution was found, but the observed findings would be quite useful in comparing similar traits of populations within Africa perhaps to establish the existence of a common descent. In conclusion, the incidence and distribution of tongue folding and tongue rolling trait have been studied and shown to be relatively higher in females than their male counterparts. It has also been shown that no significant difference exist between gender and tongue movement traits in the studied population.

ODOKUMA, E. I.; EGHWORO, O.; AVWIORO, G. \& AGBEDIA, U. Rasgos de lengua enrollada y lengua doblada en una población africana. Int. J. Morphol., 26(3):533-535, 2008.

RESUMEN: Las variaciones genéticas que ocurren en los seres humanos son, por lo general, resultado de una suma de factores de enorme valor en la antropología física, sobre todo en el estudio de variación de población y diversidad humana. Este estudio se realizó en estudiantes voluntarios no vinculados de la Universidad del Estado de Delta, Nigeria. Todos pertenecientes a la tribu Urhobo, 71 varones y 72 mujeres de 18 y más años de edad. El objetivo del estudio fue determinar su capacidad de plegamiento y enrollamiento lingual. La frecuencia de las lenguas dobladas (120) y enrolladas (87), fue mayor que las no dobladas (23) y no enrolladas (56). La incidencia de la lengua enrollada fue mayor en mujeres. Estas diferencias sin embargo, no fueron estadísticamente significantivas, p> 0,01. La frecuencia de RF se observó más alta en hombres y mujeres (38 y 43), respectivamente. 22 hombres y 17 mujeres eran capaces de doblar la lengua pero no de enrollarla. 9 hombres y 7 mujeres no fueron capaces de enrollar la lengua ni de doblarla, mientras que 2 hombres y 3 mujeres fueron capaces de enrollar la lengua pero no de doblarla.

PALABRAS CLAVE: Rasgos; Nigeria; Lengua enrollada; Lengua doblada; Género.

\section{REFERENCES}

Andy I. J. Fundamental statistics for Education and Behavioral Sciences. Oyo State, Nigeria, Kraft Books Limited, 1992.

Bhasin, M. K.; Walter, H. \& Danker-Hopfe, H. The distribution of genetical, morphological and behavioural traits among the people of Indian Region. Dehli, KamlaRaj Enterprises, 1992.

Bulliyya, G., Study on anthropogenetic traits in a Caste Group of Andhra Pradesh. Anthropologist, 5:197-9, 2003.

Gandhi, P. Tongue rolling and tongue folding among five endogenous groups of Jains. Paper presented at 3rd Annual General Conference of Ethnographic and Culture Society, Luchnow, 1976.

Hernandez, M. La movilidad del pabellon auditivo. Trab. Anthropol., XVIII:199-203, 1980.

Hsu, T. C. Tongue up folding. J. Hered., 39:187-8, 1948.

Liu, T. T. \& Hsu, T. C. Tongue rolling and Tongue folding a sample of Chinese population. J. Hered., 40:19-21, 1949.
Sokoloff, A. J. \& Deacon, T. W. Musculotopic organization of the hypoglossal nucleus in the cynomolgus monkey, Macaca fascicularis. J. Comp. Neurol., 324:81-93, 1992.

Sturtevant, A. H. A new inherited character in man: Tongue rolling. Proc. Nat. Acad. Sci., 26:100-2, 1940.

Whittinghill, M. Human genetics and its foundation. Calcutta, Oxford and IBM publication, 1970.

\section{Correspondence to: \\ Odokuma E.I. \\ Dept of Anatomy \\ Delta State University, Abraka \\ NIGERIA}

Tel: 2348035658134

Email: secretfrlesl800@yahoo.com

Received: 11-02-2008

Accepted: 23-07-2008 
